\title{
CHRISTIAN FAITH, THE ACADEMIC COMMUNITY, AND THE MAGISTERIUM
}

Among those who teach college theology many are not only concerned with the Christian tradition and faith as an identifiable academic discipline but also identify themselves as believers, as members of a community of faith, the Church. If the Church is to be, like Jesus, a lumen gentium, it ought to be seen as a beacon summoning men and illumining their existence, to provide them with hope and meaning, support and strength in their struggle to make sense of their lives and the world in which they live. It is obviously difficult for the Church to do this if all it projects to the world is a babble of voices, a group of politicized and antagonistic forces, each seeking to gain control of the other and attempting to settle disputes by epithet or edict. Unfortunately this may be the picture that the Church presents both to those "outside" and to many "within."

What can be done about this situation, and how does it bear on the work of academic theology? Some, of course, would urge a return to a more monolithic kind of Church, to a more regimented ecclesial existence. No matter what one may say against this position, it at least had the advantage of letting people know where things stood. There was no question about what it meant to be a Christian or a Catholic. To return to this state of affairs, however, would not only be unpractical, it would also be a lie.

Nonetheless some things can be done abcut the current situation, and these demand leadership from the academic community and from the hierarchy.

The reflections offered here are inspired principally by reflecting on the thought of John Courtney Murray. Murray's most famous book, We Hold These Truths, was a prolonged commentary on the political life of the American people, on the need for consensus in a pluralist society. His reflections, I believe, can be applied analogously to the life of the Church, a community that is, quite truthfully, pluralist (with differing theologies or understandings of the faith) yet one: a people united in the faith (to use the slogan of one group that typifies a conservative reactionism), in hope, and in love.

As believers Christians do hold some truths. We hold these both because they are a patrimony and because they are true. I am not going to try to spell these out (create my own credo), but I think the point is obvious. Common to Christians is the belief that there is a real, living God who is our Emmanuel, the God who became definitively with and for men in the life, death, and resurrection of Jesus of Nazareth. There can be arguments about what all this means (and hence a plurality of theologies or ways of understanding what it 
means) but these arguments make sense only because they are based on a common consensus. It is ultimately the mission of the entire community of the faithful to articulate this shared consensus-and it is a growing reality, with a cutting edge-and to express this consensus authoritatively. My presupposition is that the authoritative expression or articulation of this consensus is the function of the magisterial ministry and that this ministry cannot properly and rightfully be exercised without the collaboration of the academic community. For in articulating the faith there can be and must be argument, that is, the theological interpretation of the shared consensus. Some people, unfortunately, do not realize this; some confuse argument with dissent, with an attack on the consensus itself. The hierarchy, in whom the magisterial expression of the consensus is vested, provides the faithful an emotional stability inasmuch as it symbolizes the unity of the community. Thus it is incumbent on the hierarchy to make the faithful aware of the possibility of theological diversity. To question the understanding of the faith set forth in a particular theology is not of itself heresy or an attack on the consensus fidelium. Questioning and doubt are not incompatible with faith but rather are inextricably linked to faith.

Yet it must be possible to identify the consensus and to distinguish divergent understandings of the consensus from deformations of the consensus, that is, from dissenting views that not only offer differing interpretations of the Christian faith but do in fact eviscerate its meaning. If it is not possible to do this, then it is meaningless to speak of a consensus fidelium or a unity of faith. For if this is so vague that it can mean anything at all, then it means nothing; it is, in other words, meaningless. The task of identifying the consensus and of showing how it is compatible with divergent interpretations or theologies is, I submit, one that is primarily that of the magisterial ministry. Central to this task, moreover, is the identification of positions that are not simply differing theological understandings but genuine distortions or deformations of the faith. In addition, the magisterial ministry cannot carry out its task in this area without the collaboration of the academic community, without the help of those who are engaged by professional choice in the intelligent articulation of the faith. Those members of the believing community who are professionally committed to the intelligent articulation of the faith, that is, to theology, are performing a diakonal service or ministry. They are, in Murray's terms, the "Lords Spiritual" within the community of believers. As such they have the responsibility to help the community, and in particular those who are the symbols of its living unity, to identify emasculating deformations of the faith (what can truly be characterized as heresy) 
for what they are. This does not mean a condemnation of those who advocate such views (we need not start any witch-hunting), for they too may still be serving the community by forcing that community to sharpen its consensus and to make this consensus more articulate and more conscious in the life of the faithful. But this service of the academic community does require truthfulness on its part in the elaboration of theological understandings of the faith; it requires it to take seriously its task of distinguishing differing theological understandings of the one faith from positions that are misunderstandings, distortions, deformations of the truths that Christians hold.

I hope that the thrust of these remarks is clear. I believe that the question at the heart of the matter is one of utmost importance and seriousness, and one that cannot be sidestepped by the academic community.

- WILLIAM E. MAY

\section{LET THEOLOGY BE THEOLOGY!}

There is a touch of anxiety-if not panic-intruding into the deliberations of the curriculum committee of many theology departments this semester. The declining overall enrollment, the administrators' demands for "innovative curricula," the reduction or elimination of the theology requirement, the open competition with other departments for those abundant electives students now enjoy, all these factors powerfully influence the type of program designed for the coming term. Joined to these pressures are the tragic human dimensions which accompany the lower enrollment in theology courses: reduction in the number of faculty, loss of jobs with little hope of finding employment, delayed tenure and promotion, the lessening of faculty morale.

Most theology departments experience this tension and many respond to it in a typically American pragmatic way: the construction of a 'relevant' curriculum which no longer considers Christian revelation itself as its primary concern, or worse, gives clear priority to descriptive, phenomenological studies of interesting issues of the day. Since the overriding concern is to fill the classroom, attract students, and thereby insure faculty positions, new courses are invented which have "more appeal" to the typical undergraduate. (At times this also entails novel teaching methods such as class held amidst the deafening noise ${ }^{\circ}$ of the local pub.) The 'relevant' 